\title{
Research Paper \\ Biogeography and divergent patterns of body size disparification in North American minnows
}

\author{
Samuel D. Martin ${ }^{1 *}$ and Ronald M. Bonett ${ }^{1}$ \\ ${ }^{1}$ Department of Biological Science, The University of Tulsa, 800 S. Tucker Drive, Tulsa, OK, \\ 74104, USA. \\ ${ }^{*}$ Correspondence: Samuel D. Martin, Department of Biological Science, The University of Tulsa, \\ 800 S. Tucker Drive, Tulsa, OK 74104. E-mail: samuel.martin@utulsa.edu
}

WORD COUNT: 202 words (abstract)

WORD COUNT: 8974 words (main body)

\begin{abstract}
Body size is one of the most important traits influencing an organism's ecology and a major axis of evolutionary change. We examined body size disparification in the highly speciose North American minnows (Cyprinidae), which exhibit diverse body sizes and ecologies, including the giant piscivorous pikeminnows. We estimated a novel phylogeny for 285 species based on a supermatrix alignment of seven mitochondrial and ten nuclear genes, and used this to reconstruct ancestral body sizes (log-total length) and ancestral area.

Additionally, given that fishes inhabiting Pacific drainages have historically been subjected to frequent local extinctions due to periodic flooding, droughts, and low drainage connectivity, we also compared body size disparification between the highly speciose Atlantic drainages and comparatively depauperate Pacific drainages.

We found that dispersal between Atlantic and Pacific drainages has been infrequent and generally occurred in minnows with southerly distributions, where drainage systems are younger and less stable. The long isolation between Atlantic and Pacific drainages has allowed for divergent patterns of morphological disparification; we found higher rates of body size disparification in minnows from the environmentally harsher Pacific drainages. We propose several possible explanations for the observed patterns of size disparification in the context of habitat stability, niche space, and species diversification.
\end{abstract}

Keywords: ancestral area reconstruction; Atlantic drainage; environmental stability; macroevolution; niche space; Pacific drainage 


\section{INTRODUCTION}

Body size exerts tremendous influence on an organism's ecology (Peters, 1983; Calder, 1996; Gaston and Blackburn, 2000) and is often a major axis of evolutionary change (Streelman and Delaney, 2003). Unsurprisingly, disparification in body size is a common feature of adaptive radiations (Schluter, 2000; Kozak et al., 2005; Clabaut et al., 2007), although true bursts of morphological disparification may be rare in nature (Harmon et al., 2010).

Among freshwater fishes, body size impacts patterns of biogeography and macroevolution, as well as many other life-history characteristics (Winemiller and Rose, 1992). Fishes with larger bodies are more efficient at movement and dispersal (Bernatchez and Dodson, 1987; Roff, 1988). Larger freshwater fishes also tend to have larger geographic ranges (McAllister et al., 1986; Taylor and Gotelli, 1994; Pyron, 1999) and inhabit larger streams and rivers (Griffiths, 2010, 2012). Conversely, smaller fishes can inhabit smaller streams, are generally poorer dispersers, and are thus more likely to become isolated among drainages. Directional evolution toward smaller body size (an inverse Cope's Rule) and range size has likely promoted diversification in several groups of North American freshwater fishes (Knouft and Page, 2003), including madtom catfishes (Hardman and Hardman, 2008), suckers (Smith, 1992), and darters (Page and Swofford, 1984; Bart and Page, 1992).

The well-studied North American freshwater fish fauna exhibits pronounced gradients in species and morphological diversity, becoming more depauperate to the north and to the west. The latitudinal species diversity gradient has been extensively documented in this fauna (McAllister et al., 1986), and is due to past glacial cycles as well as current ecological variation (Bernatchez and Dodson, 1987; Bernatchez and Wilson, 1998; Knouft and Page, 2011; Griffiths, 2010, 2012). Likewise, there are trends of increasing body size (Bergmann's rule) and range size (Rapoport's rule) with latitude, largely reflecting larger fishes' improved dispersal abilities when recolonizing formerly glaciated regions (Knouft, 2004; Griffiths, 2010, 2012).

Few studies, however, have addressed differences between eastern and western North America, despite the significant ecological disparity between these regions (but see Griffiths, 2010). The arid Pacific drainage basins of western North America have been subject to frequent flooding and drying events and more recent tectonism, while their small sizes and relative isolation have prevented dispersal and recolonization by freshwater fishes, resulting in high local extinction rates (Smith, 1978, 1981; Patterson, 1981; Cross et al., 1986; Minckley et al., 1986; Fausch and Bestgen, 1996; Smith et al., 2002), particularly in the southwestern United States. Prior to anthropogenic introductions, several groups of fishes were nearly absent or extinct from Pacific drainages, including basses, pikes, catfishes, topminnows and killifishes, silversides, cavefishes, and darters (Fig. 1; Ross, 2013; Page and Burr, 2011), in contrast to the high species and ecomorphological diversity of these clades in Atlantic drainages. Their rarity or absence in Pacific drainages leads us to suggest that niche space there is relatively unsaturated.

One group of fishes which has survived and diversified in the harsh western environment is the endemic clade of North American minnows (family Cyprinidae). This clade of over 300 species exhibits extreme variation in body size and diversity, from the giant, piscivorous pikeminnows 
(which historically reached lengths up to $1.8 \mathrm{~m}$ ), to the benthic chubs and speciose, small-bodied pelagic shiners. However, macroevolutionary studies have been hampered by minnows' controversial and unstable taxonomy. In fact, their complex morphological diversity confounded early phylogenetic studies. Excluding Notemigonus crysoleucas, which is thought to be a member of the EU leuciscin clade (Saitoh et al., 2011), most authors have recognized three primary clades of North American minnows: the Open Posterior Myodome (OPM), Creek ChubPlagopterin (CC-P), and Western clades (Coburn and Cavender, 1992), although the precise compositions of these clades have been more variable (Mayden, 1989; Simons and Mayden, 1997, 1998, 1999; Simons et al., 2003; Schönhuth et al., 2008; Schönhuth and Mayden, 2010; Bufalino and Mayden, 2010a, 2010b). Only recently have systematists begun to incorporate multiple genetic markers with broader taxon sampling of North American cyprinids (Western clade: Schönhuth et al., 2012, 2014; OPM clade: Hollingsworth et al., 2013), but we still lack a comprehensive phylogenetic hypothesis for the clade as a whole.

The three recognized North American minnow clades differ in body size, diversity, and distribution. The OPM clade, found primarily in Atlantic drainages, contains nearly $80 \%$ of the species diversity, most notably the pelagic shiners. Minnows from the depauperate CC-P clade inhabit both Pacific and Atlantic drainages. Members of the aptly named Western clade are primarily found in Pacific drainages, but this clade also includes the Atlantic genus Chrosomus (formerly Phoxinus; Strange and Mayden, 2009). The Western clade contains many of the largest North American minnow species, including pikeminnows and curiously-shaped humpback chub (Gila cypha), thought to be an adaptation to the gape-limited predatory pikeminnows (Portz and Tyus, 2004). As with the North American fish fauna as a whole, the species diversity of minnows declines and their body sizes increase to the north (Lindsey, 1966; Knouft, 2004) and west.

Here, we estimated a novel and comprehensive phylogeny for North American minnows, based on a supermatrix of seven mitochondrial and ten nuclear genes, to examine their biogeography and body size evolution (disparification). To assess regional variation in size disparification, we compared rates and models of body size disparification in minnows from the Atlantic and Pacific drainage systems; these are discrete, biologically meaningful regions separated by identifiable barriers. We discuss the observed patterns of size disparification in the context of ecological and environmental differences between these two regions.

\section{METHODS AND MATERIALS}

\section{Phylogenetic reconstruction}

We used the taxon list for North American Cyprinidae from Fishbase (Froese and Pauly, 2011). We selected genes with at least ten sequences available for ingroup taxa, but excluded those with ambiguous alignments (e.g. 12s and 16s, GH, ITS). The final alignment included seven mitochondrial genes [cytochrome oxidase I (COI), cytochrome b (Cytb), NADH dehydrogenase 2 (ND2), NADH dehydrogenase 3 (ND3), NADH dehydrogenase 4 (ND4), NADH dehydrogenase 4-light strand (ND4-L), and NADH dehydrogenase 5 (ND5)] and ten nuclear genes [ectodermal-neural cortex 1 (ENC1), interphotoreceptor retinoid-binding protein 2 (IRBP2), protease III (ptr), recombination activating gene 1 (Rag1), rhodopsin (Rhod), ryanodine 
receptor $3(R Y R 3)$, ribosomal protein s7 (s7), sorting-nexin 33 (SH3PX3), t-box brain protein 1 (tbr), and zinc finger protein 1 (zic1)]. While our matrix included 17 genes, many nodes were informed by only a subset of these, due to the amount of missing data (see below). As of September 2013, there was at least one sequence of these genes available for 285 of 307 (92.8\%) extant ingroup taxa (according to species list on FishBase). We downloaded the longest available sequence for each species from Genbank, and randomly selected among sequences of the same length. We included 15 outgroup taxa, 12 from the super-family Cyprinidae and three from Catostomidae (see Appendix S1 in supporting information for species list and accession numbers for gene sequences). No IRBP sequences were available for two outgroup species, but sequences from congeners were used instead ( Tribolodon nakamurai for T. hakonensis and Danio albolineatus for D. rerio).

Alignments were performed separately for each gene using ClustalW and Muscle in the program MEGA v5.03 (Tamura et al., 2007), and adjusted by eye as needed before verifying amino acid translations for protein-coding markers. Sequences determined to be of low quality or ambiguous identity were discarded. Ends of alignments were trimmed to regions containing at least ten overlapping sequences. Taxa without data for a given marker were included in the alignments as missing data (-) for every nucleotide position, as per BEAST's requirements. The alignment matrix included 15,086 nucleotides and was $30.54 \%$ complete, including real gaps. The average taxon was represented by $5.1 \pm 3$ genes. There was a significant amount of missing data; however, these absences generally don't appear to have a major impact on phylogenetic reconstructions (Wiens, 2006; Wiens and Morrill, 2011) or divergence dates (Zheng and Wiens, 2015), and incompletely sampled genes can still improve phylogenetic resolution (Jiang et al., 2014). Sequences were distributed across taxa (Appendix S1) and the less well-sampled genes contained phylogenetic signal that helped to resolve relationships, particularly among the diverse OPM minnows. Phylogenetic analyses using only the five bestsampled genes (Cytb, Rag1, COI, s7, and Rhod) failed to approach stationarity after $2.0 \times 10^{8}$ generations, although they recovered very similar relationships among terminal taxa (not shown).We felt the potential negative effects of missing data, including inflated support values (Simmons, 2012), incorrect topologies and spurious branch lengths (Lemmon et al., 2009; but see Roure et al., 2013), were preferable to the loss of resolution which occurred when these genes were excluded. Our strategy was designed to maximize taxon sampling for macroevolutionary analyses, and our phylogenetic hypothesis is highly congruent with prior studies with narrower taxon sampling and fewer genes, but less missing data (see Results). Given the presumably rapid evolution of this group and corresponding short internal branch lengths, we felt it would be preferable to include as much data as possible to increase resolution (or at least incorporate the signals from most genes).

jModelTest2 (Guindon et al., 2003; Darriba et al., 2012) was used to determine the best substitution model for the concatenated dataset. Searches among substitution models were limited to those models available in the BEAUTi configurator, which was used to generate the .xml file for BEAST v1.7.4 (Drummond et al., 2012). We performed four Markov-Chain Monte Carlo (MCMC) searches of $1.0 \times 10^{8}$ generations in BEAST using the CIPRES Science Gateway (Miller et al., 2010), logging trees and parameters every 10,000 generations. We constrained the monophyly of the three outgroup catostomids, of Cyprinidae (ingroup plus 12 
outgroup taxa), and of North American cyprinids as a whole (ingroup); no further constraints were applied so we could assess composition of the OPM, CC-P, and Western clades. We applied a Yule process speciation prior and an uncorrelated lognormal relaxed clock rate prior (mean $=0, S D=1$ ). We linked all tree, clock, and substitution models (functionally concatenated) to reduce model complexity. Runs without monophyly constraints and unlinked clock and substitution models yielded generally comparable topologies (see Appendix S3 for an example topology), but exhibited poor convergence even after multiple runs of $3.0 \times 10^{8}$ generations. We acknowledge that concatenation may produce strongly-supported yet erroneous topologies (Lemmon and Lemmon, 2013) but the available genetic data did not permit the use of species-tree approaches, and under many conditions concatenation may perform at least as well as species-tree approaches (Tonini et al., 2015).

We used Tracer v1.5 (Drummond and Rambaut, 2007) to assess stationarity and verify that effective sample size (ESS) values were above 200 . The last $1.0 \times 10^{7}$ generations from each run were pooled before calculating the maximum clade credibility (MCC) tree using Tree Annotator. We also randomly sampled 25 trees from each run and combined these 100 trees in a file for use in analyses which incorporate phylogenetic uncertainty. Finally, catostomids, nonNorth American cyprinids, and Notemigonus were pruned from the consensus phylogeny and sample of 100 trees using the R package 'ape' (Paradis et al., 2004).

Although there are several minnow fossils available, we did not employ them for divergence dating. Most of the potentially useful representatives from the Oligocene, Miocene, and Pliocene of western North America (e.g. Smith, 1981; Cavender, 1991) are in need of reinterpretation in light of recent taxonomic revisions, especially in the Western clade (Schönhuth et al., 2012, 2014) which has presumably undergone extensive morphological evolution, including several instances of apparent convergence (e.g. pikeminnows, genus Ptychocheilus). Cyprinids are conspicuously absent from the diverse freshwater faunas of the Green River ( 50 Ma; Smith et al., 2003) and Florissant ( 34 Ma; Prothero and Sanchez, 2004) formations (Cavender, 1991). The earliest North American cyprinid fossils date to the middle Oligocene, approximately $31 \mathrm{Ma}$ (Evernden and James, 1964; Cavender, 1991). Therefore, we conservatively scaled the root of North American cyprinids in our consensus tree to $32.5 \mathrm{Ma}$. This was a period of global cooling and lineage turnover when other North American fishes also began to radiate, supported by fossil evidence (Cavender, 1986, 1998; Near and Koppelman, 2009) and divergence dating studies (Centrarchidae; Near et al., 2005, 2011). This date is far younger than that inferred by a recent biogeographical reconstruction for the age of North American minnows ( 68.2 Ma; Imoto et al., 2012), but that estimate was based on complete mitogenomic data, which is prone to saturation that may inflate divergence dates (Dornburg et al., 2014).

\section{Ancestral area reconstruction}

We reconstructed North American cyprinid ranges by dispersal-extinction-cladogenesis (DEC) in LAGRANGE (Ree et al., 2005; Ree and Smith, 2008) using the online configurator and Python. Additionally, we used RASP (Yu et al., 2015) to run S-DIVA (Yu et al., 2010) and LAGRANGE for comparison. Species were coded as occurring in one or more of the three primary drainage systems: Atlantic, Pacific, or Arctic. Coding was based on species accounts 
(especially for Mexican species; Miller et al., 2005) or by examining species' distributions with respect to the Continental (Great) Divide and Laurentian Divide. Although the present configuration of many drainages likely differs from past patterns, the Atlantic and Pacific drainage systems have been largely separate since the Laramide orogeny uplifted the Rocky Mountains in the late Mesozoic and early Cenozoic (Thornbury, 1965), and the long separation of these drainages has affected minnows (Mayden, 1991) and the freshwater fish fauna as a whole (Patterson, 1981). Thus, we consider these coarse categories representative of the general layout of North American drainages for the last $~ 30$ million years of diversification and range evolution in cyprinids.

Species whose ranges included or were limited to the endorheic Great Basin in western North America were coded as Pacific, since this basin is surrounded by Pacific drainages. There were six species endemic to Mexican endorheic basins (Miller et al., 2005); five of these were coded as Atlantic (Cyprinella bocagrande, C. alvarezdelvillari, Gila conspersa, G. nigrescens, and Notropis nazas), and one as Pacific (Algansea lacustris) based on their proximity to the respective drainages and elevational divides. Species were allowed to inhabit up to three drainages (a realistic assumption based on the distributions of extant taxa), and transition probabilities were equally weighted.

\section{Patterns of trait disparification}

As our metric for body size, we used the largest reported total lengths for each species (in millimeters) from a variety of sources, including Fishbase (Froese and Pauly, 2011), FishTraits (Frimpong and Angermeier, 2009), regional guides, and primary literature (see Appendix S2 in supporting information for trait data and sources). We did not attempt to scale up values for 32 (primarily Mexican) species with only standard lengths reported, because regression models for converting standard and total lengths are species-specific due to interspecific variation in tail length. We acknowledge this represents a source of uncontrolled variation, but note that a similar proportion of species from Atlantic (35/120, 29\%) and Pacific drainages (14/56, 25\%) only had standard lengths reported. Results of additional uncensored rate test analyses performed after pruning taxa with only standard length data were highly similar (not shown). Size data were log-transformed before analyses.

We used the program Bayestraits (Pagel and Meade, 2006) to test for phylogenetic signal (Pagel's $\lambda$; Pagel, 1997, 1999) in the log-transformed values of total length (logTL) across the sample of trees. We applied MCMC sampling and Brownian motion (BM), as the directional model was not supported (see Results). We calculated the average and standard deviation of $\lambda$. We also compared the harmonic means $(\mathrm{HM})$ of runs with $\lambda$ fixed at $0.0,0.5$, and 1.0 using a Bayes Factor (BF) comparison, where $B F=2$ (log[harmonic mean(better model)] - log[harmonic mean(worse model)]). A BF of ten is considered strong evidence for the model with the highest harmonic mean (Kass and Raftery, 1995).

We then tested the fit of five evolutionary models for the evolution of logTL in minnows: Brownian motion (BM; random walk with increasing variance), Ornstein-Uhlenbeck (OU; random walk with stabilizing selection), early burst (exponentially increasing or decreasing disparification rate), trend (diffusion model with linearly increasing or decreasing rates), and 
white noise (non-phylogenetic null model). We fitted models using fitContinuous in 'geiger' (Harmon et al., 2008) to the entire consensus phylogeny, as well as pruned subtrees including only species from Atlantic or Pacific drainages, to determine whether patterns of body size disparification showed different trends between drainage systems. We excluded Arctic drainages, since they have probably not hosted significant in-situ disparification, and no extant minnows are endemic to Arctic drainages. Model fits were assessed using the Akaike Information Criterion corrected for small sample size (AICc); a $\triangle \mathrm{AICc}$ of four is considered strong support for the model with the lowest AICc value (Burnham and Anderson, 2004).

To determine whether minnows in the Pacific drainages of western North America have experienced lower rates of body size disparification due to strong positive selection, or higher rates due to open niche space, we compared disparification rates between Atlantic and Pacific drainages. We first recoded nine species found in both Atlantic and Pacific drainages as inhabiting only Atlantic (Couesius plumbeus, Gila pulchra, Rhinichthys cataractae) or Pacific (Algansea tincella, Aztecula sallaei, Campostoma ornatum, Codoma ornata, Notropis calientis, Notropis moralesi,) drainages based on the extent of their distribution in each drainage system. Results were similar when we pruned and excluded these nine species from the analysis rather than recoding them (not shown). We then stochastically mapped the evolution of Atlantic vs. Pacific drainages for each of the 100 phylogenies in our sample using the 'make.simmap' function in 'phytools' (Revell, 2012). This accounted for uncertainty in both our phylogenetic estimate and ancestral area reconstruction. Next, we used Brownie (O'Meara et al., 2006) to perform a non-censored rates test, fitting BM models for body size disparification (other models were not strongly supported over BM for all minnows; see Results). We compared a model with a single global disparification rate against one with two different rates (for fishes in Atlantic vs. Pacific drainages), and ran each over all 100 pruned SIMMAP trees. The relative fits of the two models were assessed using AICc values.

We reconstructed the evolution of logTL on the consensus phylogeny using maximum likelihood $(\mathrm{ML})$ in 'phytools'. While estimates of fishes' ancestral body sizes could be improved with the addition of fossil data (Albert et al., 2009), the fossil record of North American minnows requires re-examination in light of taxonomic revisions, precluding accurate taxonomic assignments for potentially informative minnow fossils. Lastly, we used the VarRates option in Bayestraits to compare rates of logTL disparification among clades and regions, using the consensus phylogeny and reversible jump MCMC. This analysis produced 1000 trees, and we used Dendroscope (Huson and Scornavacca, 2012) to produce a strict consensus tree, which uses stretched or compressed branches to indicate higher or lower disparification rates, respectively.

\section{RESULTS}

\section{Phylogeny}

Our consensus phylogeny yielded strong support values (100\% Bayesian posterior probabilities) for the three primary clades (OPM, CC-P, and Western) and many recognized genera (Fig. 2). Our phylogenetic hypothesis is largely congruent with other recent but less well-sampled phylogenies (Schönhuth et al., 2012, 2014; Hollingsworth et al., 2013). We recovered a strongly supported sister relationship between the Western and CC-P clades, a result which Schönhuth 
et al. (2012) found only with mitochondrial data; this may be due to the strong mitochondrial signal in our dataset or the relatively large amount of missing nuclear data. We also recovered numerous non-monophyletic genera, most of which have been noted by previous authors; the Western clade is particularly in need of revision (e.g. Schönhuth et al., 2012, 2014), while the OPM genus Notropis has long been used as a bin for species of questionable affinity. Most notably, our phylogeny did not recover the distinctive pikeminnows (genus Ptychocheilus) as monophyletic, in agreement with other studies (Simons et al., 2003; Bufalino and Mayden, 2010a, 2010b; Houston et al., 2010; Schönhuth et al., 2012, 2014). Relationships within the hyperdiverse OPM clade were unsurprisingly less stable among runs (including many preliminary phylogenetic analyses) and among our sample of trees, and its backbone received lower support values. The low stability of and support for relationships within the OPM clade probably reflects their rapid diversification (Hollingsworth et al., 2013). Due to our partitioning strategy, we cannot comment on the degree to which hybridization or introgression may have impacted relationships among minnows.

Our alternative phylogenetic analyses (unlinked clock and substitution models, no monophyly constraints; see Appendix S3) exhibited poor convergence and did not consistently recover North American minnows as monophyletic to the exclusion of Eurasian leuciscins, which has been reported previously (Coburn and Cavender, 1992; Cunha et al., 2002; Rüber et al., 2007; Sasaki et al., 2007; Bufalino and Mayden, 2010a, 2010b; Saitoh et al., 2011; Imoto et al., 2012).

\section{Geographic range evolution}

Ancestral area reconstruction in LAGRANGE indicated that dispersal between the Atlantic and Pacific drainages has been infrequent, with only 11 reconstructed transitions (Fig. 3). Alternative analyses run in RASP reconstructed 11 (LAGRANGE) and 17 (S-Diva) transitions, respectively (Appendix S4). S-DIVA appeared to be less likely to reconstruct nodes as inhabiting multiple areas, and thus inferred a greater number of dispersal events. Most minnow diversification has occurred within the three primary drainages. Unsurprisingly, the formerly glaciated Arctic drainages have probably not been significant for extant minnows except perhaps as dispersal corridors. All three clades have extant representatives in both Atlantic and Pacific drainages. The most recent common ancestors (MRCAs) of the OPM and CC-P clades were reconstructed to have occurred in Atlantic drainages, while the MRCA of the Western clade was most likely a wide-ranging species found in both Atlantic and Pacific drainages. The deepest divergence in the Western clade (between the MRCAs of Chrosomus and the rest of the clade) was reconstructed as vicariance between the Atlantic and Pacific drainages.

Most of the Atlantic-Pacific transitions probably occurred in Mexico, since many of the reconstructed transition nodes have extant descendants whose ranges include (or are limited to) Mexico. Seven of nine extant minnow species that inhabit both Atlantic and Pacific drainages are found in Mexico, compared to only two in northern North America (lake chub, Couesius plumbeus, and longnose dace, Rhinichthys cataractae). Because the continent is longitudinally narrower in Mexico, the Atlantic and Pacific drainages are geographically proximate.

Additionally, drainage systems south of the Rocky Mountains are younger (Smith, 1981; Miller et al., 2005), due to geologically recent uplifts and volcanism since the Miocene (Ferrari et al., 
1999, 2000). Such tectonic events may have caused drainage rearrangements and thus facilitated dispersal or induced vicariance. Ongoing headwater erosion and stream captures are known to have facilitated Atlantic-Pacific transitions by minnows in southern Mexico (Schönhuth et al., 2001, 2006) and central and northern Mexico (Schönhuth et al., 2011, 2014, 2015).

\section{Trait disparification}

There was extensive body size $(\log T L)$ disparification in the Western clade, in contrast to lower amounts in the OPM and CC-P clades (Figs. 4, 5). The directional model $(\lambda=0.992, \pm 0.006$, $\mathrm{HM}=71.6)$ was not supported over a BM model $(\lambda=0.994, \pm 0.007, \mathrm{HM}=71.2, \mathrm{BF}=0.86)$ for body size across minnows. We found strong phylogenetic signal in body size; $\lambda=1.0(\mathrm{HM}=$ 74.5) was supported over $\lambda=0.5(\mathrm{HM}=53.2, \mathrm{BF}=42.59)$ and $\lambda=0.0(\mathrm{HM}=-26.8, \mathrm{BF}=$ 202.57).

The early burst model was supported weakly over BM and strongly over all other models for the disparification of logTL across North American minnows (Table 1). The white noise (nonphylogenetic) model was strongly supported for Atlantic minnows, and the OU model was supported weakly over the trend model and strongly over other models for Pacific minnows (Table 1).

Rates of $\log T L$ disparification were higher in Pacific drainages $(4.516, \pm 0.290)$ than in Atlantic drainages $(0.643, \pm 0.166$; Fig. 5$)$. The two-rate BM model $(\mathrm{AICC}=-159.4)$ was strongly supported over the one-rate BM model $(\mathrm{AICC}=-22.9)$ for the disparification of $\log T \mathrm{TL}(\triangle \mathrm{AICc}=$ 117.6).

\section{DISCUSSION}

The rarity of dispersals between Atlantic and Pacific drainages by minnows indicates that the Continental Divide has been a major physical or ecological boundary to dispersal throughout the history of this clade (Fig. 3; Mayden, 1991). Most lineage diversification has therefore occurred in-situ within Atlantic or Pacific drainages; this regional endemism allowed us to test for divergent patterns of body size disparification which may have evolved in response to differing environmental conditions and community compositions. We found strong phylogenetic signal for the disparification of body size using our comprehensive phylogeny. Using a smaller subset of 21 OPM minnows, Gotelli and Pyron (1991) also found that closely related minnows had more similar body sizes than distant relatives. However, while directional evolution towards small body size has contributed to a high rate of species diversification in many fishes (Page and Swofford, 1984; Bart and Page, 1992; Smith, 1992; Turner and Trexler, 1998; Knouft and Page, 2003; Hardman and Hardman, 2008), we found no support for a directional model of body size disparification across North American minnows or within drainages. Knouft and Page (2003) also did not find evidence for a trend of decreasing size with increasing clade rank in North American minnows, although the early phylogenetic estimate they used (Coburn and Cavender, 1992) excluded the Western clade, which contains most of the largest minnow species. However, we did find support for an early burst model of size disparification across North American minnows. This probably reflects the high body size disparity among clades and drainages, which evolved relatively rapidly (Figures 4,5 ). 
In contrast to adaptive radiations (in which rates of species diversification and ecomorphological disparification are often coupled; Schluter, 2000; Clabaut et al., 2007; Rabosky et al., 2013) and nonadaptive radiations (in which species diversify with little apparent ecomorphological disparification; Gittenberger, 1991; Rundell and Price, 2009; Kozak et al., 2006), we found that minnows from Pacific drainages exhibited high rates of body size disparification despite their low extant species diversity. In contrast, minnows from Atlantic drainages are highly speciose, but exhibited low rates of morphological disparification. Therefore, it appears that species diversification and morphological disparification may be uncoupled in Atlantic and Pacific minnows, as in some clades of plethodontid salamanders (Adams et al., 2009). We postulate that the divergent trends in species diversification and body size disparification may have been produced by different factors. Our results agree with evidence from the fossil record demonstrating rapid body size changes in minnows from western North America (Smith, 1981).

The high rates of body size disparification in Pacific drainages and the Western clade, which contains the largest North American minnows, may indicate that there have also been frequent reversals to smaller body sizes. While Pacific drainages contain several large migratory species, there are also numerous local endemics with very small ranges (e.g. Gila brevicauda, G. purpurea, and Moapa coriacea). Such populations may frequently become isolated, diverge, and eventually go extinct over evolutionary time, due to the increased extinction risk for species with small ranges (Gaston, 1994; Gaston and Blackburn, 1996a), particularly in harsh or unpredictable habitats. However, if body size is correlated with range size in minnows, as in many other taxa (reviewed by Gaston and Blackburn, 1996b; 1996c), then these narrowly endemic minnows may have contributed enough decreasing body size signal to impact our disparification comparisons. High disparification rates may also have resulted if the magnitude of body size changes is positively correlated with body size; sturgeons, which have some of the largest bodies among actinopterygians, have similarly elevated rates of body size disparification (Rabosky et al., 2013). The frequency and magnitude of body size changes may both have contributed to high disparification rates.

Additionally, while harsh conditions and low drainage connectivity in Pacific drainages have eliminated or prevented colonization by many clades of fishes, the resultant open niche space may have facilitated ecological and morphological disparification by western minnows. Many diverse clades of fishes from eastern North America are nearly absent or extinct from Pacific drainages, including walleye and saugers, topminnows and killifishes, silversides, darters, catfishes (with the exception of the Yaqui catfish, Ictalurus pricel), and basses (except the Sacramento perch, Archoplites interruptus) (Fig. 1; Page and Burr, 2011). If the higher rates of body size disparification in Pacific drainages resulted from open niche space, we predict that body size should be correlated with other indicators of ecomorphological disparification, such as trophic niche or oral morphology. Most notably, the evolution of pikeminnows may be due to the rarity or absence of other large, piscivorous freshwater fishes. Pikeminnows were formerly such dominant predators in the Colorado River basin that two other large sympatric fishes (humpback chub, Gila cypha, and razorback sucker, Xyrauchen texanus) are thought to have evolved their distinctive but energetically costly humped backs in response to predation by the gape-limited pikeminnows (Portz and Tyus, 2004). Our phylogenetic estimate indicates that pikeminnows have evolved independently up to three times, in agreement with other studies (Simons et al., 
2003; Bufalino and Mayden, 2010a, 2010b; Houston et al., 2010; Schönhuth et al., 2012, 2014). Like all cyprinids, these piscivores lack oral teeth, and are poor competitors against introduced basses, catfishes, and northern pike (Tyus and Saunders, 1996). If their evolution was facilitated by the absence of other large piscivores, then the fossil record should show no evidence that pikeminnows were both spatially and temporally sympatric with catfishes, pike, walleyes, or basses.

Nearly all of the largest North American minnows inhabit Pacific drainages; there are several reasons why larger body size might be favored in unstable habitats. First, large body size may be related to longevity and thus an adaptation to buffer the effects of habitat unpredictability. Larger, long-lived fishes are more likely to survive multi-year droughts when spawning is unsuccessful, and can produce relatively large numbers of eggs when favorable conditions return (Tyus, 1986; Mueller and Marsh, 2002). Second, the unpredictable Pacific drainages contain several long-distance migrants, which tend to be larger-bodied (Griffiths, 2010) due in part to the reduced energetic costs of swimming long distances for larger fishes (Bernatchez and Dodson, 1987; Roff, 1988; Lucas and Baras, 2001). The opposing selection pressures for large body size in unpredictable environments and small size in narrowly endemic species may explain the fit of the OU (stabilizing selection) model for Pacific minnows.

The low species diversity of Pacific minnows likely resulted from harsh environmental conditions. Habitat instability and low drainage connectivity have caused frequent local extinctions in the Pacific drainages of western North America (Smith, 1978, 1981; Patterson, 1981; Cross et al., 1986; Minckley et al., 1986; Fausch and Bestgen, 1996; Smith et al., 2002). In contrast, the highly interconnected Atlantic drainage basins have allowed species to shift their ranges in response to changing environmental conditions and recolonize areas from which they were formerly extirpated (e.g. post-glacial dispersal). Although accurately estimating extinction rates from molecular phylogenies alone is difficult (Rabosky, 2010; Quental and Marshall, 2010), it would be informative to test whether extinction rates have indeed been higher in Pacific minnows.

The small body sizes and low rates of size disparification in Atlantic minnows (primarily the OPM clade) may have contributed to their high species diversity. Hollingsworth et al. (2013) recently concluded that a shift from benthic to pelagic habits promoted species diversification in OPM minnows by allowing locally sympatric species to partition the water column by depth. Our reconstructions indicate that OPM minnows evolved small body sizes relatively early in their diversification, with little disparification thereafter (Fig. 4). It would be instructive to determine whether the benthic-pelagic habitat shift was coeval with the evolution of small body size, since small fishes should be better able to partition stream habitats. The Atlantic drainages and OPM clade contain more resident species, which tend to have smaller bodies and thus may inhabit smaller streams, compared to migratory species (Griffiths, 2010, 2012). The relative stability of headwater habitats in Atlantic drainages, particularly in areas with springs, may allow specialization to such habitats. Headwater species may become isolated among drainages more frequently, increasing the likelihood of vicariant speciation (Mahon, 1984). Small minnows also have shorter generation times, which may predispose species to diversification (Marzluff and Dial, 1991). Both small body size (with its life history correlates) and pelagic habits likely 
contributed to the high local (Baker and Ross, 1981; Gorman, 1988a, 1988b) and regional diversity of OPM minnows in Atlantic drainages. The low size disparity and disparification rates observed in Atlantic minnows also explain the fit of the white noise (non-phylogenetic) model of size disparification.

\section{Conclusions}

Body size has tremendous impact on ecology, and should evolve in response to differing environmental conditions among regions. North American minnows have rarely dispersed between Atlantic and Pacific drainages, allowing time for divergent patterns of species diversification and ecomorphological disparification. The few minnow taxa which have managed to persist in the environmentally harsh and isolated Pacific drainage basins showed high rates of body size disparification. We suggest this may be due to open niche space, as well as the opposing selection forces for larger body size in unpredictable environments and smaller size in endemic species with small ranges. In contrast to the patterns observed in the west, the hyperdiverse minnow assemblage in the Atlantic drainage basins of eastern North America showed low rates of body size disparification. We propose this is a result of habitat stability, which in turn has promoted residency, specialization (microhabitat partitioning), and headwater invasions. Future studies should test our proposed explanations for divergent patterns of diversification and disparification in minnows.

\section{ACKNOWLEDGEMENTS}

We thank G. Louthan (Tandy Supercomputing Center) and M. Miller (CIPRES Science Gateway) for support during supercomputing analyses. This work was supported by a grant from the National Science Foundation (DEB1050322) and an Oklahoma Department of Wildlife Conservation State Wildlife Grant, both to RMB.

\section{SUPPORTING INFORMATION}

Additional Supporting Information may be found in the online version of this article:

Appendix S1 Taxon names and Genbank accession numbers.

Appendix S2 Body size data, drainage coding, and literature sources for ingroup taxa.

Appendix S3 Example alternative phylogeny, showing areas of topological uncertainty and low support.

Appendix S4 Alternative ancestral area reconstructions (LAGRANGE and S-Diva) performed in RASP. 


\section{REFERENCES}

Adams, D.C., Berns, C.M., Kozak, K.H., Wiens, J.J., 2009. Are rates of species diversification correlated with rates of morphological evolution? Proc. R. Soc. B, 276, 2729-2738.

Albert, J.S., Johnson, D.M., Knouft, J.H., 2009. Fossils provide better estimates of ancestral body size than do extant taxa in fishes. Acta Zool., 90, 357-384.

Baker, J.A., Ross, S.T., 1981. Spatial and temporal resource utilization by southeastern cyprinids. Copeia, 1981, 178-189.

Bart, H.L., Page, L.M., 1992. The influence of size and phylogeny on life history variation in North American percids. In: Mayden, R.L. (ed). Systematics, historical ecology, and North American freshwater fishes. Stanford University Press, Stanford, CA, pp. 553-572.

Bernatchez, L., Dodson, J.J., 1987. Relationship between bioenergetics and behavior in anadromous fish migrations. Can. J. Fish. Aquat. Sci., 44, 399-407.

Bernatchez, L., Wilson, C.C., 1998. Comparative phylogeography of Nearctic and Palearctic fishes. Mol. Ecol., 7, 431-452.

Bufalino, A.P., Mayden, R.L., 2010a. Molecular phylogenetics of North American phoxinins (Actinopterygii: Cypriniformes: Leuciscidae) based on RAG1 and S7 nuclear DNA sequence data. Mol. Phylogenet. Evol., 55, 274-283.

Bufalino, A.P., Mayden, R.L., 2010b. Phylogenetic evaluation of North American Leuciscidae (Actinopterygii: Cypriniformes: Cyprinoidea) as inferred from analyses of mitochondrial and nuclear DNA sequences. Syst. Biodivers., 8, 493-505.

Burnham, K.P., Anderson, D.R., 2004. Multimodel inference understanding AIC and BIC in model selection. Sociol. Methods. Res., 33, 261-304.

Calder, W.A., 1996. Size, function, and life history. Courier Dover Publications, Mineola, NY.

Cavender, T.M., 1986. Review of the fossil history of North American freshwater fishes. In: Hocutt, C.H., Wiley, E.O. (eds). The zoogeography of North American freshwater fishes. John Wiley and Sons, New York, NY, pp. 699-724.

Cavender, T.M., 1991. The fossil record of the Cyprinidae. In: Winfield, I.J., Nelson, J.S. (eds). Cyprinid fishes. Springer, Netherlands, pp. 34-54.

Cavender, T.M., 1998. Development of the North American Tertiary freshwater fish fauna with a look at parallel trends found in the European record. Ital. J. Zool., 65, 149-161.

Clabaut, C., Bunje, P.M.E., Salzburger, W., Meyer, A., 2007. Geometric morphometric analyses provide evidence for the adaptive character of the Tanganyikan cichlid fish radiations. Evolution, $61,560-578$. 
Coburn, M.M., Cavender, T.M., 1992. Interrelationships of North American cyprinid fishes. In: Mayden, R.L. (ed). Systematics, historical ecology, and North American freshwater fishes. Stanford University Press, Stanford, CA, pp. 328-373.

Cross, F.B., Mayden, R.L., Stewart, J.D., 1986. Fishes in the Western Mississippi Basin (Missouri, Arkansas and Red Rivers). In: Hocutt, C.H., Wiley, E.O. (eds). The zoogeography of North American freshwater fishes. John Wiley and Sons, New York, NY, 363-412.

Cunha, C., Mesquita, N., Dowling, T.E., Gilles, A., Coelho, M.M., 2002. Phylogenetic relationships of Eurasian and American cyprinids using cytochrome b sequences. J. Fish Biol., 61, 929-944.

Darriba, D., Taboada, G.L., Doallo, R., Posada, D., 2012. jModelTest 2: more models, new heuristics and parallel computing. Nat. Methods, 9, 772.

Dornburg, A., Townsend, J.P., Friedman, M., Near, T.J., 2014. Phylogenetic informativeness reconciles ray-finned fish molecular divergence times. BMC Evol. Biol., 14, 169.

Drummond, A.J., Rambaut, A., 2007. Tracer v1.4. Available from http://beast.bio.ed.ac.uk/Tracer

Drummond, A.J., Suchard, M.A., Xie, D., Rambaut, A., 2012. Bayesian phylogenetics with BEAUti and the BEAST 1.7. Mol. Biol. Evol., 29, 1969-1973.

Evernden, J.F., James, G.T., 1964. Potassium-argon dates and the Tertiary floras of North America. Am. J. Sci., 262, 945-974.

Fausch, K.D., Bestgen, K.R., 1996. Ecology of fishes indigenous to the central and southwestern Great Plains. In: Knopf, F.L., Sampson, F.B. (eds). Ecology and conservation of Great Plains vertebrates. Springer-Verlag, New York, NY, pp. 131-166.

Ferrari, L., Lopez-Martínez, M., Aguirre-Díaz, G., Carrasco-Nuñez, G., 1999. Space-time patterns of Cenozoic arc volcanism in central Mexico: From the Sierra Madre Occidental to the Mexican Volcanic Belt. Geology, 27, 303-306.

Ferrari, L., Petrone, C., Conticelli, S., Vaggelli, G., 2000. Late Miocene volcanism and intra-arc tectonics during the early development of the Trans-Mexican Volcanic Belt. Tectonophysics, $318,161-185$.

Frimpong, E.A., Angermeier, P.L., 2009. FishTraits: A database of ecological and life-history traits of freshwater fishes of the United States. Fisheries, 34, 487-493.

Froese, R., Pauly, D. (Eds)., 2011. FishBase. Available: www.fishbase.org, accessed July 2013. Gaston, K.J., 1994. Rarity. Chapman \& Hall, London.

Gaston, K.J., Blackburn, T.M., 1996a. Conservation implications of geographic range size-body size relationships. Conserv. Biol., 10, 638-646. 
Gaston, K.J., Blackburn, T.M., 1996b. Range size-body size relationships: Evidence of scale dependence. Oikos, 75, 479-485.

Gaston, K.J., Blackburn, T.M., 1996c. Global scale macroecology: interactions between population size, geographic range size and body size in the Anseriformes. J. Anim. Ecol., 65, 701-714.

Gaston, K.J., Blackburn, T.M., 2000. Pattern and process in macroecology. Blackwell Science, Oxford.

Gittenberger, E., 1991. What about non-adaptive radiation? Biol. J. Linn. Soc., 43, 263-272.

Gorman, O. T., 1988a. The dynamics of habitat use in a guild of Ozark minnows. Ecol. Monogr., $58,2-18$.

Gorman, O.T., 1988b. An experimental study of habitat use in an assemblage of Ozark minnows. Ecology, 69, 1239-1250.

Gotelli, N.J., Pyron, M., 1991. Life history variation in North American freshwater minnows: effects of latitude and phylogeny. Oikos, 62, 30-40.

Griffiths, D., 2010. Pattern and process in the distribution of North American freshwater fish. Biol. J. Linn. Soc., 100, 46-61.

Griffiths, D., 2012. Body size distributions in North American freshwater fish: large-scale factors. Global Ecol. Biogeogr., 21, 383-392.

Guindon, S., Gascuel, O., 2003. A simple, fast and accurate method to estimate large phylogenies by maximum-likelihood. Syst. Biol., 52, 696-704.

Harmon, L.J., Weir, J.T., Brock, C.D., Glor, R.E., Challenger, W., 2008. GEIGER: investigating evolutionary radiations. Bioinformatics, 24, 129-131.

Harmon, L.J., Losos, J.B., Jonathan Davies, T., Gillespie, R.G., Gittleman, J.L., Bryan Jennings, W., Kozak, K.H., McPeek, M.A., Moreno-Roark, F., Near, T.J., Purvis, A., Ricklefs, R.E., Schluter, D., Schulte, J.A., II, Seehausen, O., Sidlauskas, B.L., Torres-Carvajal, O., Weir, J.T., Mooers, A.Ø., 2010. Early bursts of body size and shape evolution are rare in comparative data. Evolution, 64, 2385-2396.

Hardman, M., Hardman, L.M., 2008. The relative importance of body size and paleoclimatic change as explanatory variables influencing lineage diversification rate: an evolutionary analysis of bullhead catfishes (Siluriformes: Ictaluridae). Syst. Biol., 57, 116-130

Hollingsworth, P.R., Simons, A.M., Fordyce, J.A., Hulsey, C.D., 2013. Explosive diversification following a benthic to pelagic shift in freshwater fishes. BMC Evol. Biol., 13, 272. 
Houston, D.D., Ogden, T.H., Whiting, M.F., Shiozawa, D.K., 2010. Polyphyly of the pikeminnows (Teleostei: Cyprinidae) inferred using mitochondrial DNA sequences. T. Am. Fish. Soc., 139, 303-315.

Huson, D.H., Scornavacca, C., 2012. Dendroscope 3- An interactive viewer for rooted phylogenetic trees and networks, Syst. Biol., 61, 1061-1067.

Imoto, J.M., Saitoh, K., Sasaki, T., Yonezawa, T., Adachi, J., Kartavtsev, Y.P., Miya, M., Nishida, M., Hanzawa, N., 2012. Phylogeny and biogeography of highly diverged freshwater fish species (Leuciscinae, Cyprinidae, Teleostei) inferred from mitochondrial genome analysis. Gene, 514, 112-124.

Jiang, W., Chen, S.Y., Wang, H., Li, D.Z., Wiens, J.J., 2014. Should genes with missing data be excluded from phylogenetic analyses? Mol. Phylogenet. Evol., 80, 308-318.

Kass, R.E., Raftery, A.E., 1995. Bayes factors. J. Am. Statist. Assoc., 90, 773-795.

Knouft, J.H., 2004. Latitudinal variation in the shape of the species body size distribution: an analysis using freshwater fishes. Oecologia, 139, 408-417.

Knouft, J.H., Page, L.M., 2003. The evolution of body size in extant groups of North American freshwater fishes: speciation, size distributions, and Cope's rule. Am. Nat., 161, 413-421.

Knouft, J.H., Page, L.M., 2011. Assessment of the relationships of geographic variation in species richness to climate and landscape variables within and among lineages of North American freshwater fishes. J. Biogeogr., 38, 2259-2269.

Kozak, K.H., Larson, A.A., Bonett, R.M., Harmon, L.J., 2005. Phylogenetic analysis of ecomorphological divergence, community structure, and diversification rates in dusky salamanders (Plethodontidae: Desmognathus). Evolution, 59, 2000-2016.

Kozak, K.H., Weisrock, D.W., Larson, A., 2006. Rapid lineage accumulation in a non-adaptive radiation: phylogenetic analysis of diversification rates in eastern North American woodland salamanders (Plethodontidae: Plethodon). Proc. R. Soc. B, 273, 539-546.

Lemmon, A.R., Brown, J.M., Stanger-Hall, K., Lemmon, E.M. 2009. The effect of ambiguous data on phylogenetic estimates obtained by maximum likelihood and Bayesian inference. Syst. Biol., 58, 130-145.

Lemmon, E.M., Lemmon, A.R., 2013. High-throughput genomic data in systematics and phylogenetics. Annu. Rev. Ecol. Evol. Syst., 44, 99-121.

Lindsey, C.C., 1966. Body sizes of poikilotherm vertebrates at different latitudes. Evolution, 20, 456-465.

Lucas, M.C., Baras, E., 2001. Migration of freshwater fishes. Blackwell Science, Oxford.

Mahon, R., 1984. Divergent structure in fish taxocenes of north temperate streams. Can. J.

Fish. Aquat. Sci., 41, 330-350. 
Marzluff, J.M., Dial, K.P., 1991. Life history correlates of taxonomic diversity. Ecology, 72, 428439.

Mayden, R.L., 1989. Phylogenetic studies of North American minnows, with emphasis on the genus Cyprinella (Teleostei: Cypriniformes). Misc. publ. Univ. Kans. Mus. Nat. Hist., 80, 1-189.

Mayden, R.L., 1991. Cyprinids of the new world. In: Winfield, I.J., Nelson, J.S. (eds). Cyprinid Fishes. Springer Netherlands, pp. 240-263.

McAllister, D.E., Platania, S.P., Schueler, F.W., Baldwin, M.E., Lee, D.S., 1986. Ichthyofaunal patterns on a geographic grid. In: Hocutt, C.H., Wiley, E.D. (eds). The zoogeography of North American freshwater fishes. John Wiley and Sons, New York, NY, pp. 17-51.

Miller, R.R., Minckley, W.L., Norris, S.M., 2005. Freshwater fishes of Mexico. University of Chicago Press, Chicago, IL.

Miller, M.A., Pfeiffer, W., Schwartz, T., 2010. Creating the CIPRES Science Gateway for inference of large phylogenetic trees. In: Gateway Computing Environments Workshop, New Orleans, 2010, 1-8.

Minckley, W.L., Hendrickson, D.A., Bond, C.E., 1986. Geography of western North American freshwater fishes: Description and relationships to intracontinental tectonism. In: Hocutt, C.H., Wiley, E.O. (eds). The zoogeography of North American freshwater fishes. John Wiley and Sons, New York, NY, 519-613.

Mueller, G.A., Marsh, P.C., 2002. Lost, a desert river and its native fishes: A historical perspective of the lower Colorado River (No. USGS/BRD/ITR--2002--0010). Geological survey, Fort Collins Science Center Co.

Near, T.J., Bolnick, D.I., Wainwright, P.C., 2005. Fossil calibrations and molecular divergence time estimates in centrarchid fishes (Teleostei: Centrarchidae). Evolution, 59, 1768-1782.

Near, T.J., Bossu, C.M., Bradburd, G.S., Carlson, R.L., Harrington, R.C., Hollingsworth, P.R., Keck, B.P., Etnier, D.A., 2011. Phylogeny and temporal diversification of darters (Percidae: Etheostomatinae). Syst. Biol., 60, 565-595.

Near, T.J., Koppelman, J.B., 2009. Species diversity, phylogeny, and phylogeography of Centrarchidae. In: Cooke, S., Phillipp, D.P. (eds). Centrarchid fishes: Diversity, biology, and conservation. Blackwell Science, London, pp. 1-38.

O'Meara, B.C., Ane, C., Sanderson, M.J., Wainwright, P.C., 2006. Testing for different rates of continuous trait evolution using likelihood. Evolution 60, 922-933.

Page, L.M., Burr, B.M., 2011. A field guide to freshwater fishes: North America north of Mexico. Houghton Mifflin Harcourt, Boston, MA.

Page, L.M., Swofford, D.L., 1984. Morphological correlates of ecological specialization in darters. Environ. Biol. Fishes, 11, 139-159. 
Pagel, M., 1997. Inferring evolutionary processes from phylogenies. Zoologica Scripta, 26, 331348.

Pagel, M., 1999. The maximum likelihood approach to reconstructing ancestral character states of discrete characters on phylogenies. Syst. Biol., 48, 612-622.

Pagel, M., Meade, A., 2006. BayesTraits. Available at:

http://www.evolution.reading.ac.uk/BayesTraits.html.

Paradis, E., Claude, J., Strimmer, K., 2004. APE: analyses of phylogenetics and evolution in R language. Bioinformatics, 20, 289-290.

Patterson, C., 1981. The development of the North American fish fauna: a problem of historical biogeography. In: Forey, P.L. (ed). The evolving biosphere. Cambridge University Press, Cambridge, U.K., pp. 265-281.

Peters, R.H., 1983. The ecological implications of body size. Cambridge University Press, Cambridge, U.K.

Portz, D., Tyus, H., 2004. Fish humps in two Colorado River fishes: a morphological response to cyprinid predation? Environ. Biol. Fishes, 71, 233-245.

Prothero, D.R., Sanchez, F., 2004. Magnetic stratigraphy of the upper Eocene Florissant Formation, Teller County, Colorado. Bull. New Mexico Mus. Nat. Hist. Sci., 26, 129-135.

Pyron, M.A., 1999. Relationships between geographical range size, body size, local abundance, and habitat breadth in North American suckers and sunfishes. J. Biogeogr., 26, 549-558.

Quental, T.B., Marshall, C.R., 2010. Diversity dynamics: molecular phylogenies need the fossil record. Trends Ecol. Evol., 25, 434-441.

Rabosky, D.L., 2010. Extinction rates should not be estimated from molecular phylogenies. Evolution, 64, 1816-1824.

Rabosky, D.L., Santini, F., Eastman, J., Smith, S.A., Sidlauskas, B., Chang, J., Alfaro, M.E., 2013. Rates of speciation and morphological evolution are correlated across the largest vertebrate radiation. Nat. Commun., 4, 1-8.

Ree, R.H., Smith, S.A., 2008. Maximum-likelihood inference of geographic range evolution by dispersal, local extinction, and cladogenesis. Syst. Biol., 57, 4-14.

Ree, R.H., Moore, B.R., Webb, C.O., Donoghue, M.J., 2005. A likelihood framework for inferring the evolution of geographic range on phylogenetic trees. Evolution, 59, 2299-2311.

Revell, L.J., 2012. phytools: An R package for phylogenetic comparative biology (and other things). Methods Ecol. Evol., 3, 217-223.

Roff, D.A., 1988. The evolution of migration and some life history parameters in marine fishes. Environ. Biol. Fishes, 22, 133-146. 
Ross, S.T., 2013. Ecology of North American Freshwater Fishes. University of California Press, Berkeley, CA.

Roure, B., Baurain, D., Philippe, H., 2013. Impact of missing data on phylogenies inferred from empirical phylogenomic data sets. Mol. Biol. Evol., 30, 197-214.

Rüber, L., Kottelat, M., Tan, H.H., Ng, P.K., Britz, R. 2007. Evolution of miniaturization and the phylogenetic position of Paedocypris, comprising the world's smallest vertebrate. BMC Evol. Biol., 7, 38.

Rundell, R.J., Price, T.D., 2009. Adaptive radiation, nonadaptive radiation, ecological speciation and nonecological speciation. Trends Ecol. Evol., 24, 394-399.

Saitoh, K., Sado, T., Doosey, M.H., Inoue, J.G., Nishida, M., Mayden, R.L., Miya, M. 2011. Evidence from mitochondrial genomics supports the lower Mesozoic of South Asia as the time and place of basal divergence of cypriniform fishes (Actinopterygii: Ostariophysi). Zool. J. Linn. Soc., 161, 633-662.

Sasaki, T., Kartavtsev, Y.P., Chiba, S.N., Uematsu, T., Sviridov, V.V., Hanzawa, N. 2007. Genetic divergence and phylogenetic independence of Far Eastern species in subfamily Leuciscinae (Pisces: Cyprinidae) inferred from mitochondrial DNA analyses. Genes Genet. Syst., 82, 329-340.

Schluter, D., 2000. The ecology of adaptive radiation. Oxford University Press, Oxford.

Schönhuth, S., Mayden, R.L., 2010. Phylogenetic relationships in the genus Cyprinella (Actinopterygii: Cyprinidae) based on mitochondrial and nuclear gene sequences. Mol. Phylogenet. Evol., 55, 77-98.

Schönhuth, S., Blum, M.J., Lozano-Vilano, L., Neely, D.A., Varela-Romero, A., Espinosa, H., Perdices, A., Mayden, R.L., 2011. Inter-basin exchange and repeated headwater capture across the Sierra Madre Occidental inferred from the phylogeography of Mexican stonerollers. J. Biogeogr., 38, 1406-1421.

Schönhuth, S., De Sostoa, A., Martinez, E., Doadrio, I., 2001. Southern Mexican minnows of the genus Notropis (Actinopterygii, Cyprinidae): genetic variation, phylogenetic relationships and biogeographical implications. Biochem. Syst. Ecol., 29, 359-377.

Schönhuth, S., Doadrio, I., Dominguez-Dominguez, O., Hillis, D.M., Mayden, R.L., 2008. Molecular evolution of southern North American Cyprinidae (Actinopterygii), with the description of the new genus Tampichthys from central Mexico. Mol. Phylogenet. Evol., 47, 729-756.

Schönhuth, S., Doadrio, I., Mayden, R.L., 2006. A biogeographic perspective on the phylogeny of Mexican cyprinids (Actinopterygii, Cyprinidae). In: Studies of North American desert fishes: in honor of EP (Phil) Pister, conservationist. Universidad Autónoma de Nuevo León, Monterrey, Nuevo León, Mexico, pp. 102-124. 
Schonhuth, S., Lozano-Vilano, L., Perdices, A., Espinosa, H., Mayden, R.L., 2015. Phylogeny, genetic diversity and phylogeography of the genus Codoma (Teleostei, Cyprinidae). Zool. Scr., $44,11-28$.

Schönhuth, S., Perdices, A., Lozano-Vilano, L., García-de-León, F.J., Espinosa, H., Mayden, R.L., 2014. Phylogenetic relationships of North American western chubs of the genus Gila (Cyprinidae, Teleostei), with emphasis on southern species. Mol. Phylogenet. Evol., 70, 210230.

Schönhuth, S., Shiozawa, D.K., Dowling, T.E., Mayden, R.L., 2012. Molecular systematics of western North American cyprinids (Cypriniformes: Cyprinidae). Zootaxa, 3586, 281-303.

Simmons, M.P. 2012. Radical instability and spurious branch support by likelihood when applied to matrices with non-random distributions of missing data. Mol. Phylogenet. Evol., 62, 472-484.

Simons, A.M., Mayden, R.L., 1997. Phylogenetic relationships of the creek chubs and the spinefins: an enigmatic group of North American cyprinid fishes (Actinopterygii: Cyprinidae).

Cladistics, 13, 187-205.

Simons, A.M., Mayden, R.L., 1998. Phylogenetic relationships of the western North American phoxinins (Actinopterygii: Cyprinidae) as Inferred from mitochondrial 12S and 16S ribosomal RNA sequences. Mol. Phylogenet. Evol., 9, 308-329.

Simons, A.M., Mayden, R.L., 1999. Phylogenetic relationships of North American cyprinids and assessment of homology of the open posterior myodome. Copeia, 1999, 13-21.

Simons, A.M., Berendzen, P.B., Mayden, R.L., 2003. Molecular systematics of North American phoxinin genera (Actinopterygii: Cyprinidae) inferred from mitochondrial $12 \mathrm{~S}$ and $16 \mathrm{~S}$ ribosomal RNA sequences. Zool. J. Linnean Soc., 139, 63-80.

Smith, G.R., 1978. Biogeography of intermountain fishes. Gt. Basin Nat. Mem., 17-42.

Smith, G.R., 1981. Late Cenozoic freshwater fishes of North America. Annu. Rev. Ecol. Evol. Syst., 12, 163-193.

Smith, G.R., 1992. Phylogeny and biogeography of the Catostomidae, freshwater fishes of North America and Asia. In: Mayden, R.L. (ed). Systematics, historical ecology, and North American freshwater fishes. Stanford University Press, Stanford, CA, pp. 778-826.

Smith, G.R., Dowling, T.E., Gobalet, K.W., Lugaski, T.S., Shiozawa, D.K., Evans, R.P., 2002. Biogeography and timing of evolutionary events among Great Basin fishes. Gt. Basin Aquat. Syst. Hist., 33, 175-234.

Smith, M.A., Singer, B., Carroll, A., 2003. ${ }^{40} \mathrm{Ar} /{ }^{39} \mathrm{Ar}$ geochronology of the Eocene Green River Formation, Wyoming. Geol. Soc. Am. Bull., 115, 549-565. 
Strange, R.M., Mayden, R.L., 2009. Phylogenetic relationships and a revised taxonomy for North American cyprinids currently assigned to Phoxinus (Actinopterygii:

Cyprinidae). Copeia, 2009, 494-501.

Streelman, J.T., Danley, P.D., 2003. The stages of vertebrate evolutionary radiation. Trends Ecol. Evol., 18, 126-131.

Tamura, K., Dudley, J., Nei, M., Kumar, S., 2007. MEGA: Molecular Evolutionary Genetics Analysis (MEGA) software. Mol. Biol. Evol., 24, 1596-1599.

Taylor, C.M., Gotelli, N.J., 1994. The macroecology of Cyprinella: correlates of phylogeny, body size, and geographical range. Am. Nat., 144, 549-569.

Thornbury, W.D., 1965. Regional geomorphology of the United States. John Wiley and Sons, New York, NY.

Tonini, J., Moore, A., Stern, D., Shcheglovitova, M., Ortí, G. 2015. Concatenation and Species Tree Methods Exhibit Statistically Indistinguishable Accuracy under a Range of Simulated Conditions. PLOS Currents Tree of Life, Edition 1. doi:

10.1371/currents.tol.34260cc27551a527b124ec5f6334b6be.

Turner, T.F., Trexler, J.C., 1998. Ecological and Historical Associations of Gene Flow in Darters (Teleostei: Percidae). Evol., 52, 1781-1801.

Tyus, H.M., 1986. Life strategies in the evolution of the Colorado squawfish (Ptychocheilus lucius). West. N. Am. Naturalist, 46, 656-661.

Tyus, H.M., Saunders, J. F. III., 1996. Nonnative fishes in natural ecosystems and a strategic plan for control of nonnatives in the Upper Colorado River basin. Draft report. Center for Limnology, University of Colorado, Boulder, Colorado. For the recovery implementation program for endangered fish species in the upper Colorado River basin. Cooperative Agreement No. 1448-0006-923, U.S. Fish and Wildlife Service, Denver, Colorado.

Wiens, J.J., 2006. Missing data and the design of phylogenetic analyses. J. Biomed. Inform., 39, 34-42.

Wiens, J.J., Morrill, M.C., 2011. Missing data in phylogenetic analysis: Reconciling results from simulations and empirical data. Syst. Biol., 60, 719-731.

Winemiller, K.O., Rose, K.A., 1992. Patterns of life-history diversification in North American fishes: implications for population regulation. Can. J. Fish. Aquat. Sci., 49, 2196-2218.

Yu, Y., Harris, A.J., Blair, C., He, X. 2015. RASP (Reconstruct Ancestral State in Phylogenies): a tool for historical biogeography. Mol. Phylogenet. Evol., 87, 46-49.

Yu, Y., Harris, A. J., He, X. 2010. S-DIVA (Statistical Dispersal-Vicariance Analysis): a tool for inferring biogeographic histories. Mol. Phylogenet. Evol., 56, 848-850. 
Zheng, Y., Wiens, J.J. 2015. Do missing data influence the accuracy of divergence-time estimation with BEAST? Mol. Phylogenet. Evol., 85, 41-49. 
Figure 1: Diversity of 24 families of North American primary freshwater fishes in Atlantic (black) and Pacific (gray) drainages, based on Page and Burr (2011). Bars represent the number of species from each clade found in the respective drainage basins. Species inhabiting both Atlantic and Pacific drainages were counted toward each total, so the combined numbers of species are be slightly elevated for some clades. Species counts do not include Mexico.

Figure 2: BEAST consensus phylogeny for North American minnows (Cyprinidae), with outgroups and three ingroup clades labeled. Bayesian posterior support values labeled for nodes with $<100 \%$ support; all unlabelled nodes received $100 \%$ support. Outgroups were pruned prior to all analyses.

Figure 3: BEAST chronogram of North American minnows (Cyprinidae), with branches and terminal nodes color-coded according to highest probability ancestral area reconstruction in LAGRANGE: red (Pacific), blue (Atlantic), purple (Atlantic+Pacific), green (Atlantic+Arctic), and gray (all three drainages). LAGRANGE support values labeled at nodes with alternative reconstructions. Species distributed partially or entirely within Mexico are denoted by white asterisks in terminal node boxes. No nodes were reconstructed as Arctic only, and no extant species are endemic to Arctic drainages. Outgroups were pruned before reconstruction. Inset map of North America shows distribution of three primary drainage categories with colors corresponding to the tree, except that two endorheic basins in Mexico are shown in gray, and the scale bar represents $400 \mathrm{~km}$.

Figure 4: Disparification of log-total length in North American minnows, reconstructed on the consensus phylogeny using maximum likelihood in 'phytools' (Revell, 2012). Warmer colors (e.g. reds) represent smaller body sizes. The three clades are labeled: Creek Chub-Plagopterin (CC-P), highlighted in pale blue; Western, highlighted in pale pink; and Open Posterior Myodome (OPM), not highlighted.

Figure 5: Disparification of log-transformed total length in North American minnows. Tree is a strict consensus of 1000 runs using the VarRates command in Bayestraits (Pagel and Meade, 2006) over the consensus phylogeny. Stretched branches represent higher disparification rates, and compressed branches represent lower disparification rates. Branches are color-coded according to highest probability ancestral area reconstruction in LAGRANGE: red (Pacific), blue (Atlantic), purple (Atlantic+Pacific), green (Atlantic+Arctic), orange (Pacific+Arctic), and gray (all three drainages); no nodes were reconstructed as Arctic only and no extant species are endemic to Arctic drainages. Representative silhouettes shown in gray for the three clades, from top to bottom: Semotilus (CC-P clade, highlighted in pale blue), Ptychocheilus (Western clade, highlighted in pale pink), and Notropis (OPM clade, not highlighted).

Table 1: $\triangle A I C c$ values for five macroevolutionary models for the evolution of log $T L$ in North American (NA) minnows. Models were fitted to the entire consensus phylogeny, as well as pruned subtrees including only species from Atlantic or Pacific drainages, using the $r$ package 'geiger' (Harmon et al., 2008). Zeroes denote the best models; a $\triangle \mathrm{AICc}$ of 4 or more is considered strong support for the model with the lowest AICc value (Burnham and Anderson, 2004). 
Table 1

\begin{tabular}{lrrr} 
Model & NA & Atlantic & Pacific \\
\hline BM & 2.0 & 114.1 & 6.3 \\
OU & 39.5 & 122.7 & 0 \\
White noise & 6.9 & 0 & 20.5 \\
Early Burst & 0 & 112.1 & 8.5 \\
Trend & 23.0 & 119.0 & 3.2
\end{tabular}



0
$\begin{array}{lll}0.1 & 0.2 & 0.3\end{array}$
0.4
0.5
0.6
$0.7 \quad 0.8$

Cyprinidae Percidae

Catostomidae Salmonidae Cottidae Ictaluridae Poeciliidae

Cyprinodontidae Centrarchidae Fundulidae Osmeridae Esocidae Clupeidae Goodeidae Acipenseridae Gasterosteidae Percopsidae Elassomatidae Amblyopsidae Lepisosteidae Moronidae | Embiotocidae Atherinopsidae Hiodontidae ]

Pacific \%

-Atlantic \% 

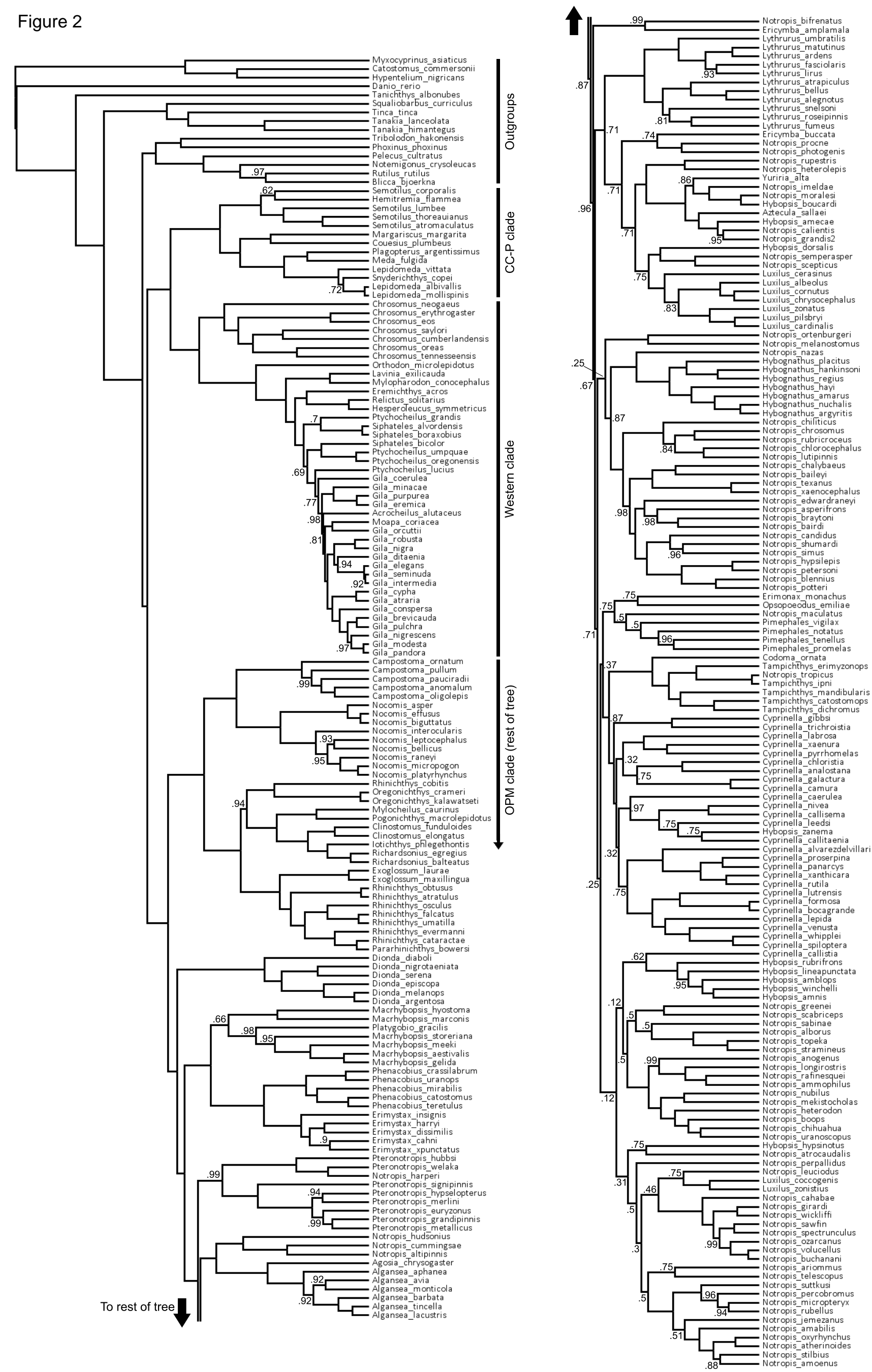
Figure 3

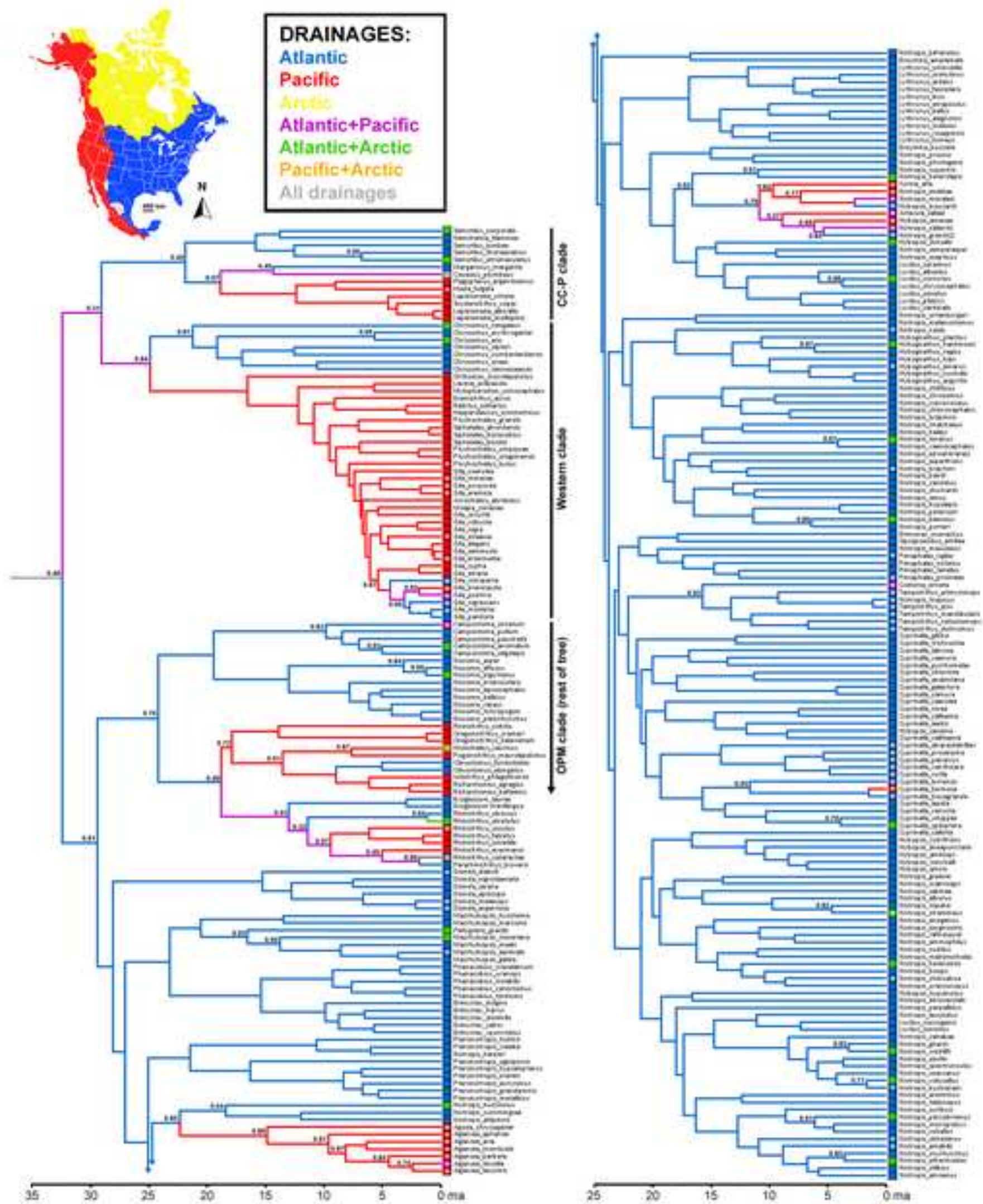


Figure 4

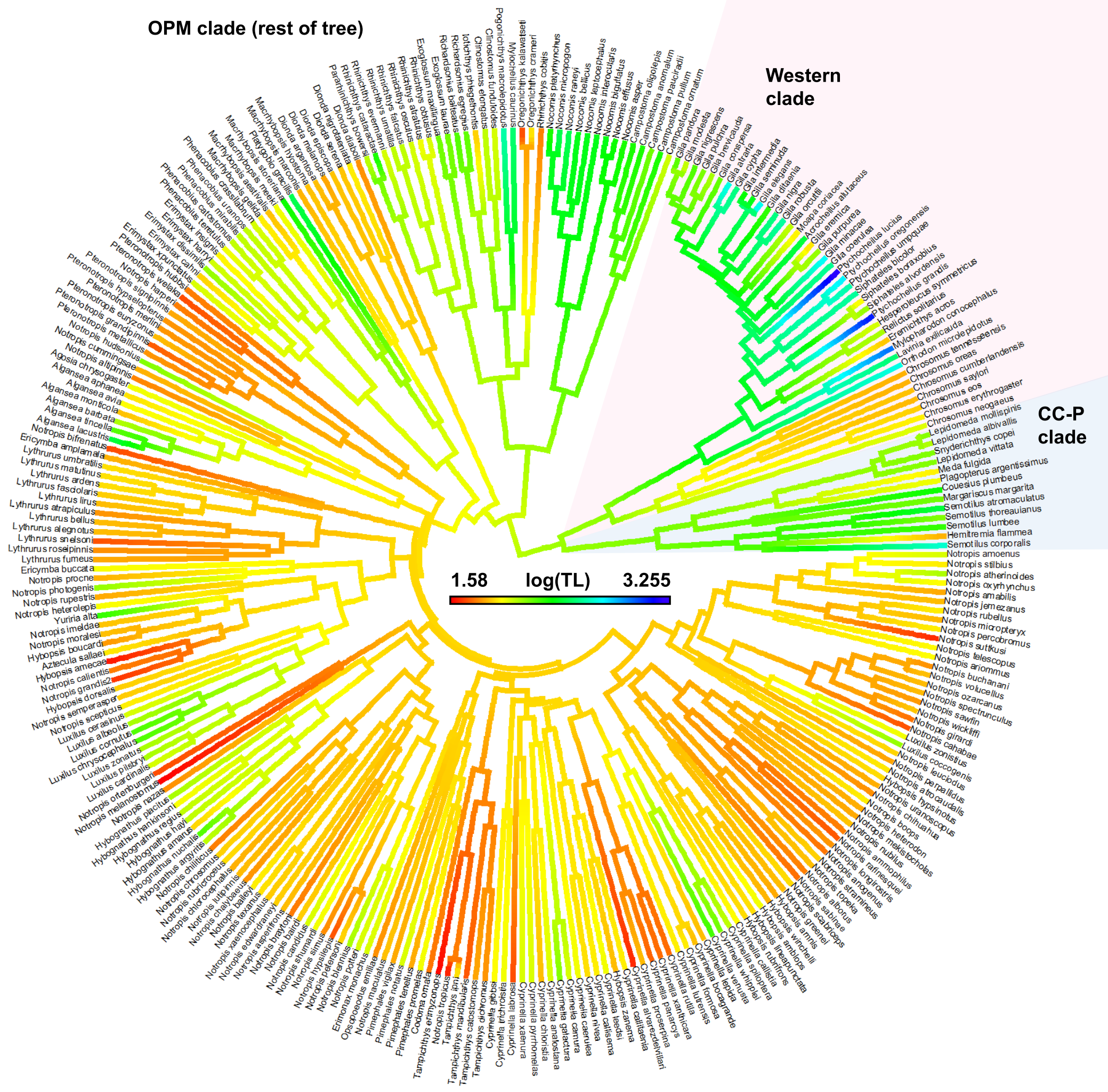




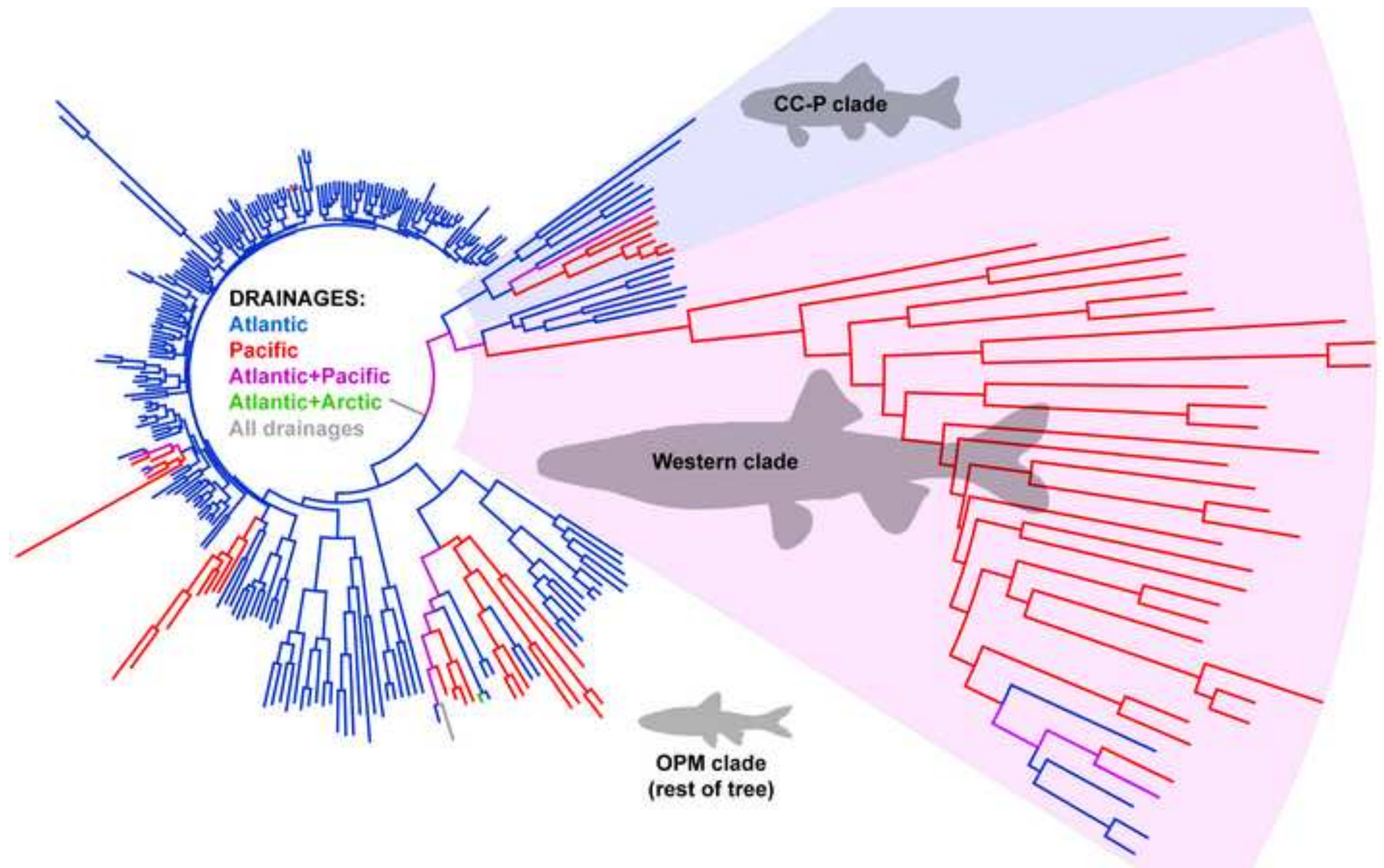




\section{Graphical abstract}

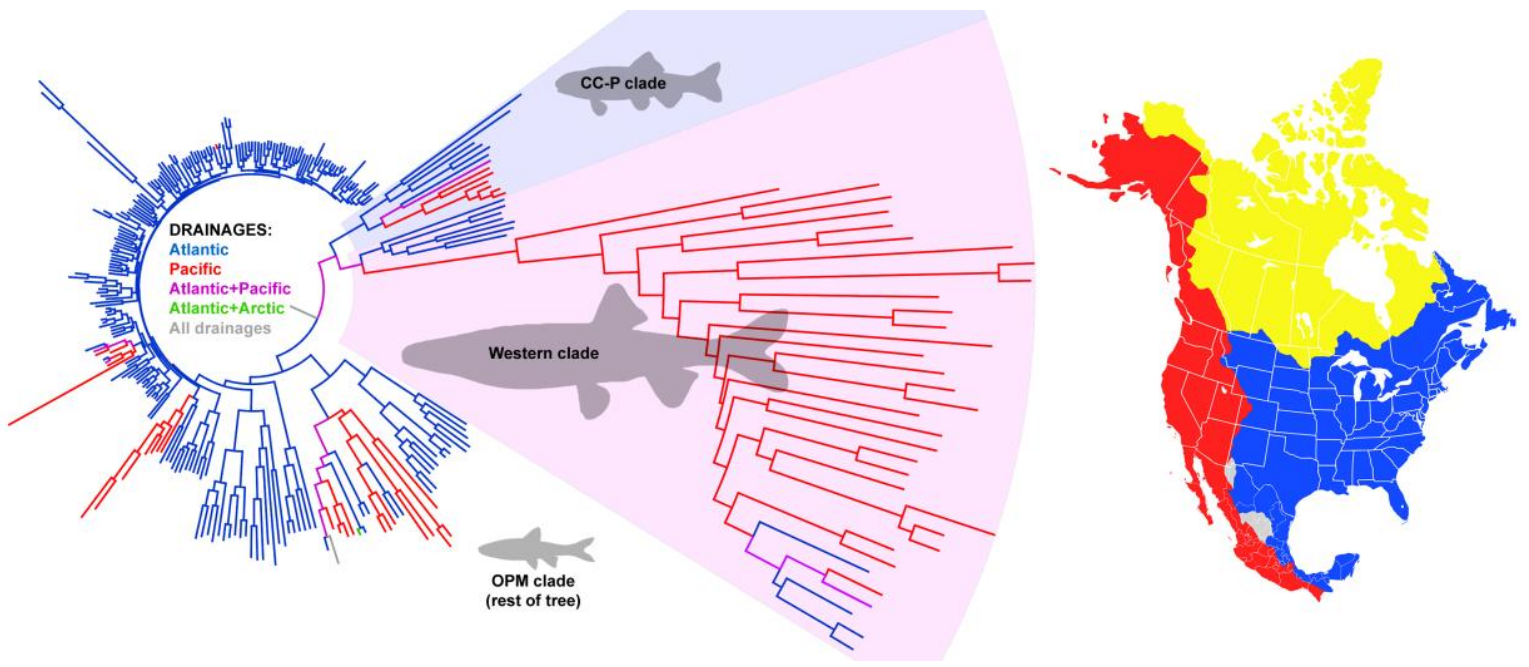

